\title{
Social Reality, the Boundaries of Self-fulfilling Prophecy, and Economics
}

Felin, Teppo; Foss, Nicolai J.

Document Version

Final published version

Publication date:

2008

License

CC BY-NC-ND

Citation for published version (APA):

Felin, T., \& Foss, N. J. (2008). Social Reality, the Boundaries of Self-fulfilling Prophecy, and Economics. Center for Strategic Management and Globalization. SMG Working Paper No. 19/2008

Link to publication in CBS Research Portal

\section{General rights}

Copyright and moral rights for the publications made accessible in the public portal are retained by the authors and/or other copyright owners and it is a condition of accessing publications that users recognise and abide by the legal requirements associated with these rights.

\section{Take down policy}

If you believe that this document breaches copyright please contact us (research.lib@cbs.dk) providing details, and we will remove access to the work immediately and investigate your claim. 
SOCIAL REALITY, THE BOUNDARIES OF SELF-FULFILLING PROPHECY, AND ECONOMICS*

Teppo Felin

Nicolai J. Foss

SMG WP 19/2008

June 25, 2008 
SMG Working Paper No. 19/2008

June 25, 2008

ISBN: 978-87-91815-32-4

Center for Strategic Management and Globalization Copenhagen Business School

Porcelænshaven 24

2000 Frederiksberg

Denmark

www.cbs.dk/smg 


\title{
SOCIAL REALITY, THE BOUNDARIES OF SELF-FULFILLING PROPHECY,
} AND ECONOMICS ${ }^{*}$

\author{
TEPPO FELIN \\ Marriott School \\ Brigham Young University \\ 587 Tanner Building \\ Provo, UT 84602 \\ $801422-3478$ (o), $801422-0539$ (f) \\ teppo.felin@byu.edu \\ NICOLAI J. FOSS \\ Center for Strategic Management and Globalization \\ Copenhagen Business School \\ Porcelainshaven $24,2^{\text {nd }}$ floor \\ 2000 Frederiksberg, Denmark \\ $n j f . s m g @ c b s . d k$
}

Organization Science (forthcoming)

\footnotetext{
* We thank Peter Abell, Bill Hesterly, Brayden King, Peter G. Klein, Siegwart Lindenberg, and Margit Osterloh for their helpful comments. Special thanks to the editor of Organization Science, Linda Argote, and anonymous reviewers for their thorough feedback and guidance. We also appreciate the helpful comments received from seminars at the Marriott School, BYU and the David Eccles School of Business, University of Utah and Free University, Amsterdam. All errors are our own.
} 


\title{
SOCIAL REALITY, THE BOUNDARIES OF SELF-FULFILLING PROPHECY, AND ECONOMICS
}

\begin{abstract}
Organizational scholars have recently argued that economic theories and assumptions have adversely shaped management practice and human behavior, leading not only to the incorporation of trust-eroding market-mechanisms into organizations but also unnecessarily creating self-interested behavior. A number of highly influential papers have argued that the self-fulfilling nature of (even false) theories provides the underlying mechanism through which economics has adversely shaped not just social science but also management practice and individual behavior. We question these arguments, and argue that there are important boundary conditions to theories falsely fulfilling themselves, boundary conditions that have hitherto been unexplored in organizational research, and boundary conditions which question the underlying premises used by organizational scholars and social scientists to attack economics. We specifically build on highly relevant findings from social psychology, philosophy and organizational economics to show how (1) objective reality and (2) human nature provide two important boundary conditions for theories (falsely or otherwise) fulfilling themselves. We also defend organizational economics, specifically the use of high-powered incentives in organizations, and argue that self-interest (rightly understood) facilitates in creating beneficial individual and collective and societal outcomes.
\end{abstract}

KEY WORDS: organization theory and social reality, organizational economics, philosophy of social science 


\section{INTRODUCTION: THE OTHER SIDE OF THE ARGUMENT}

Organizational scholars have recently challenged the application and use of economics in management research and practice. For example, in a recent award-winning paper Ferraro, Pfeffer and Sutton (2005) argue that the language and assumptions of economics have adversely influenced human behavior, specifically creating more self-interested behavior and also leading to the widespread acceptance of trust-eroding market mechanisms and bad management practices within organizations. Ghoshal and Moran (1996) have made similar points by arguing that the prescriptions and assumptions of economic theories have led to increased self-interest and bad management practice. Organizational scholars have also recently argued that there are (both direct and indirect) causal links not just between the widespread acceptance, teaching and diffusion of economic theories and bad management practice, but also between the teaching of economics in business schools and recent corporate ethics scandals (e.g., Adler 2002, Adler and Jermier 2005, Ferraro et al. 2005, Ghoshal 2003, 2005, Gintis and Khurana 2007, Harris and Bromiley 2007, Khurana 2007, Pfeffer 1997, 2005).

Organizational scholars have thus far spoken with a seemingly unified voice in challenging economic theories in their role in adversely shaping human behavior and in adversely influencing management practice. Very few defenses of economic reasoning have been published in the organizational literature (see Williamson 1996, Zenger and Hesterly 1997), and importantly, the more general logic of the self-fulfilling nature of (false economic) theories has not been questioned or challenged. Unfortunately scholars directly implicated by these arguments-namely scholars in economics and other disciplines such as psychology and philosophy—are unlikely to be aware of these discussions in management journals; and, even if they were, they may not have inclinations to write an article providing the other side of the argument. 
The specific goal of this paper, then, is to provide the other side of the argument, that is, to defend organizational economics and to in part question the apparent consensus regarding economics adversely shaping human behavior, management practice and organizational outcomes (e.g., Ferraro et al. 2005, Ghoshal and Moran 1996, cf. Khurana 2007). Note, however, that the goal of this paper is not to defend all economic assumptions (for example, agent omniscience or hyper-rationality); rather, we focus on those elements of economic theory which have recently been highlighted by management scholars as having adverse effects. We specifically respond to these extant arguments by carefully discussing the underlying theoretical and philosophical assumptions that management scholars have made when linking economic theories with the suggested adverse effects on human behavior and management practice. That is, arguments related to theory (and associated assumptions) shaping or determining human behavior in self-fulfilling fashion (Ferraro et al. 2005, Ghoshal and Moran 1996) directly implicate disciplines such as social psychology and philosophy. We therefore cite and build on key theoretical and empirical insights from these disciplines not only to question these arguments but also to highlight different conclusions. Importantly, we explicate the boundaries for the self-fulfilling nature of theories and highlight an alternative interpretation for why and how (economic or other) theories influence reality. Key insights from organizational economics also feature prominently in our discussion. For example, we discuss the important role that selfinterested behavior — that is, self-interest "rightly understood" — has in creating beneficial collective outcomes. Furthermore, we discuss how self-interested behavior scarcely precludes cooperation, trust or any other human or organizational virtue. We also highlight the benefits associated with "markets in hierarchy" (Zenger and Hesterly 1997).

Note that for purposes of parsimony we will largely concentrate on the arguments made by Ferraro, Pfeffer and Sutton (2005) — henceforth referred to as "FPS" in this article - as this awardwinning and already highly-cited article is one of the latest, most sophisticated, theoretically 
consistent and strong statements about the self-fulfilling nature of theories: specifically the case of economics adversely and "falsely" shaping human behavior and management practice. We thus recognize and note that there are a host of other papers published in a wide variety of management outlets making broadly related arguments about economics adversely shaping behavior and more generally about the self-fulfilling nature of (even false) theories (e.g., Adler 2002, Adler and Heckscher 2006, Astley 1985, Astley and Zammuto 1992, Barley and Kunda 1992, Cannella and Paetzold 1994, Frey and Osterloh 2005, Ghoshal and Moran 1996, Ghoshal 2005, Green 2004, Khurana 2007, McKinley, Mone, and Moon 1999, Pfeffer 1997, 2005).

\section{THE RELATIONSHIP BETWEEN THEORY AND SOCIAL REALITY: SOME BACKGROUND}

The key mechanism that has been proposed for driving the suggested adverse influence that economic theories (and associated assumptions and language) has had on human behavior, management practice, and organizational outcomes is the self-fulfilling or reflexive nature of theories (FPS, Ghoshal and Moran 1996, Pfeffer 1997). That is, while theories have traditionally been conceptualized as tools for understanding and explaining (a given) reality (Goldman 1999, Nagel 1961, Popper 1972), a relatively recent argument is that there is a strong reflexive nature between theories and reality (Bloor 1991, Knorr-Cetina 1999, Kuhn 1970): theories and associated language and assumptions in effect shape, construct and determine reality in self-fulfilling fashion rather than merely describing or explaining reality. In fact - and this will prove critical for our subsequent arguments - the argument is not just that theories influence reality in self-fulfilling and reflexive fashion, as management scholars we all indeed hope that this is the case, but rather, the "strong form" of the argument is that even false theories and associated false specifications of reality in effect 
evoke behaviors, in self-fulfilling fashion, "which make the originally false conception come true" (Merton 1948: 195, italics in original, FPS: 8).

It is this very tradition, specifically its strong form where even false theories also fulfill themselves, that FPS build on: the false prediction and assumption of individual self-interest from economics creates self-interested behavior in self-fulfilling fashion, with the theory diffusing into management practice via the assumptions and language of economics. ${ }^{1}$ Put differently, FPS argue that economic theories do not explain reality (at least initially); rather, the false expectation of selfinterested behavior by economic theories creates self-interested behavior in self-fulfilling fashion. Economics, then, only "explains" reality and behavior post hoc, that is, after its assumptions become widely adopted and subsequently reflected in the behavior of individuals.

The idea that theorizing affects the objects of theorizing — notions of self-fulfilling prophecy or "reflexivity" — has been an important one in sociology since Thomas (1923) and Merton (1948) (e.g., Giddens 1990, Bourdieu 1992), and has become an anchoring foundation in the sociology of knowledge, particularly in the literature on the social construction of knowledge and reality, and the problem of "truth" (e.g., Barnes and Bloor 1982, Bloor 1991, Kuhn 1970, Latour 1999). The reflexive and self-fulfilling nature of theories has also been a reoccurring theme in economics (in connection with predictions and the modeling of expectations) (Grunberg and Modigliani 1954, Lucas 1977), and it has been treated by philosophers as well (Popper 1957).

\section{The Need to Specify Boundaries for the Self-Fulfilling Nature of Theories}

The strong forms of the self-fulfilling nature of theories and language are sobering because, if true, they threaten the fundamental definition of science and theory as an attempt to understand and predict objective reality (see Goldman 1999, Popper 1972, Psillos 1999). Specifically, the selffulfilling nature of even false theories makes deeply problematic such traditional scientific notions as explanation, prediction, description, understanding and control. To illustrate: the theoretically all- 
important “why”-question (Popper 1972, cf. Nagel 1961) — for example, why someone behaved or acted in a certain way — in a rather sobering twist gets explained by theories and associated language itself rather than being based on any underlying realities or human universals that might explain that behavior (cf. Brown 1991). The strong form of the argument is also sobering as it makes scientists and scholars themselves (in some part) directly responsible for how individuals behave this indeed is the explicit argument by FPS with regard to the false assumptions of economics and the resultant, self-fulfilling self-interested behavior (FPS: 15, also see Adler 2002, Ghoshal 2005, Pfeffer 2005).

But, a key problem in citing or evoking the self-fulfilling nature of theories and language is the lack of boundaries in making these arguments, that is, scholars have not been clear about the “conditions that limit prophecy fulfillment" (Jussim 1986: 429, cf. Henshel 1982). It is not clear when exactly theories and associated language are self-fulfilling, and, whether theories and associated language in all situations - again, even when based on false premises, as is explicitly argued by FPS in terms of economics - create and construct the very reality that the theory seeks to explain. A natural extension of FPS, and related strong forms of the argument, is that any (even false) reality can be created through theory, language and prophecy, which subsequently fulfills itself. Clearly this does not sound plausible. Thus, an examination of the boundaries for selffulfilling prophecy is needed.

\section{BOUNDARIES FOR THE SELF-FULFILLING NATURE OF THEORIES: OBJECTIVE REALITY AND HUMAN NATURE}

We discuss two important boundary conditions delimiting the extent to which theories, particularly false ones, are self-fulfilling: 1) objective reality and 2) human nature. We highlight theoretical, logical and empirical evidence, which shows that objective reality and human nature 
provide important boundaries for self-fulfilling prophecy, boundaries that have yet to be articulated in management research, and boundaries which make the strong forms of self-fulfilling prophecy tenuous to accept. We specifically utilize many of the same examples as FPS (from economics and social psychology), and explain how a sensitivity to these boundaries fundamentally changes their underlying conclusions.

\section{The Boundary of Objective Reality}

An important boundary of self-fulfilling prophecy, with momentous consequences for FPS's argument, is objective reality. In discussing objective reality as the boundary for self-fulfilling prophecy we adopt the position of "scientific realism," that is, the argument that there are objective facts and truths in the social world (independent of our theories about them), and that science, including organization and management science, fundamentally is about explanation and understanding (Goldman 1999, Popper 1972, Psillos 1999). ${ }^{2}$ Note that this realist perspective scarcely precludes the fact that theories can and do shape social reality and behavior. We will in fact delineate the reasons why and how true theories indeed affect the objects that they theorize about, and discuss why and how theories influence human behavior and management practice more generally. However, our reasons for why and when theories shape social reality will be fundamentally different from the ones articulated by FPS (see FPS: 10-17).

To then highlight how objective reality provides an important boundary for the self-fulfilling prophecy nature of theories we discuss two key sub-points: (a) why and how theories affect reality, and (b) objective reality and assumptions about rationality.

Why and how do theories affect and shape reality? While this may seem simplistic and naive, we argue that theories affect reality when they are true (see Bonjour 1999, Goldman 1999, Popper 1972). Or put differently, self-fulfilling prophecies based on true predictions, rather than false ones, affect reality. (We will also concurrently explicate how false theories may shape reality in 
the short-term.) Theories then affect reality because they capture and explain underlying objective realities better than alternative conceptualizations of that reality (Psillos 1999).

To illustrate our point, consider the Chicago Board of Exchange (CBE) and the influence that the Black-Scholes model had on its operations. We specifically use CBE and the Black-Scholes model as an example as FPS (12-13; Fourcade, 2007a: 1025) argue that there is "no clearer demonstration" of the self-fulfilling nature of economic theories (also see MacKenzie and Millo 2003, MacKenzie 2006). In short, FPS's argument is that rather than merely explaining the market or helping us understand markets and options prices, the Black-Scholes model corrected and constructed new market dynamics at CBE, specifically where within days the prices of options reflected the reality and assumptions of the Black-Scholes model itself. The argument, then, is that financial models in effect cause or construct markets in "performative" fashion (see Callon 1998, MacKenzie 2006, MacKenzie and Millo 2003) rather than merely helping us explain or understand them.

We agree that the Black-Scholes model affected reality, specifically, option prices. But, the key question is, why? It is critical to note that the reason the Black-Scholes model affected reality was because the model helped better explain — though not perfectly — the underlying realities about a "truer" value of option prices that existed (Black and Scholes 1973). Thus, not just any (false or other) prophecies and theoretical claims about option value could be made by these scholars; rather, the underlying realities that the model tapped into better explained a more true value of options and thus not only helped explain options prices, but, the model also in turn helped shape and change option prices themselves (cf. MacKenzie 2006). The important point here is that because theories are better than alternative explanations in terms of describing and explaining and approximating truth or reality, they then in turn create associated real value and are thus "self-fulfilling." In the physical sciences similarly, we would not argue that Einstein somehow in self-fulfilling fashion created or 
constructed nature (or, that Pasteur created microbes - though, see this argument by Latour and Woolgar 1979, cf. Psillos 1999); or put even more strongly, that Einstein could have created just any false conceptions of nature that would subsequently fulfill themselves. Rather, Einstein's correct (or rather, better) theories and models about objective reality help us first to understand and explain objective reality, and secondarily his (more) correct theories have been harnessed toward various (good and bad) uses (see Boghossian 2006, Brown 1994, 2001, cf. Goldman 1999). Thus we certainly recognize that theories have a reflexive loop where they also shape reality and behavior, but they do so first and foremost when they are better (or "truer") than alternative explanations at capturing underlying realities.

In contrast, note that FPS specifically argue that the reason why economics has become selffulfilling (or, why it influences reality) is because economics "dominates the discourse" (see FPS: 18, also see Fourcade 2007b, Knorr-Cetina 1999, cf. Kitcher 2003). Thus, the reasons why the theory is influential specifically then has more to do with social power and the widespread diffusion and acceptance of the discipline of economics rather than any real reasons related to the accuracy of economic theories themselves in capturing reality (FPS specifically cite Dumont 1977 and FourcadeGourinchas 2004 in making this case; also see Bloor 1991, Callon 1998, Knorr-Cetina 1999, Kuhn 1970). In fact, it is the explicit argument of FPS that critical parts of economic theory are false. ${ }^{3} \mathrm{We}$ of course do not question the fact that false theories propagate themselves; history provides more than ample evidence that wrong theories have widely propagated themselves (Bloor 1991). However, the readily evident historical and scientific accumulation of truths and objective facts suggests that theoretical progress is the overall mode of science (Niiniluoto 1984, Popper 1972), specifically where increasingly better, more correct, or "truer" models and approximations of reality also then in turn help to shape that reality over time (Psillos 1999, also see Boghossian 2006, Brown 1994, 2001, Goldman 1999). The natural sciences provide an example of this progression toward "truth," where 
“Einstein's theory offered a better approximation to truth than Newton's theory, and Newton's theory in turn offered a better approximation of truth than Kepler's theory" (Popper 1972: 59, Psillos 1999).

To further illustrate how objective reality puts a boundary on the self-fulfilling nature of theories; consider the question of why some assumptions of economic theories have not fulfilled themselves, while others have. Specifically, while FPS focus on the self-fulfilling nature of the assumption of self-interest, neoclassical economics has traditionally also made strong assumptions of agent omniscience or hyper-rationality. The assumption of hyper-rationality means that agents have full knowledge of (their own and other agents') preferences and choices and the consequences of associated actions; hence for example the assumption of fully efficient markets (cf. Friedman 1953). However, it is quite clear that despite the dominance and power of economics in the social sciences (FPS), the theoretical assumption of agent omniscience has not fulfilled itself. This raises the question, why do some aspects of economic theory (or other theories for that matter) appear to be self-fulfilling (such as self-interest), while others are not (such as hyper-rationality)?

The answer is that objective reality intervenes: the boundary of objective reality means that not just any false theoretical claims, assumptions, or prophecies can be made, which would subsequently be fulfilled; some things simply are not possible (cf. Popper 1972). Now, economists have traditionally pointed to "economic fundamentals" as objective social constraints, and these fundamentals place constraints on self-fulfilling prophecy. For example, scarcity is everywhere, economizing is imperative. However, economizing with scarce mental resources precludes agent omniscience from becoming a self-fulfilling prophecy (cf. Simon 1954). Specifically, the economic assumption of agent omniscience is based on a false and unrealistic conception of human decisionmaking capabilities, and thus has not fulfilled itself in the real world despite being central to and pervasive in economics. The assumption of omniscience of course has been used as a convenient tool for simplifying arguments and models regarding markets (though, also challenged by many in economics, see Hayek 1945). But, the more important and instructive point to note here is that agent 
omniscience has not fulfilled itself despite it being central to key strands of economics. The assumption of omniscience has specifically not fulfilled itself as it is not true and thus underlying objective realities about human capabilities provide a boundary for prophecy fulfillment. In other words, there is an objective social reality that provides a boundary for prophecy fulfillment, or, conversely, an underlying real basis for accepting the reasons for why a particular prophecy or theory might fulfill itself (cf. Boudon 1998).

Objective reality and assumptions about rationality. The arguments of FPS about the false fulfillment of prophecy, reveals much about their underlying assumptions about human rationality and information availability: even false definitions of situations cause individuals to behave in an irrational manner and in collectively hurtful ways. This in fact, FPS argue, is perhaps the most critical point of their paper: "Perhaps the most important implication of this paper is that theories become dominant when their language is widely and mindlessly used and their assumptions become accepted and normatively valued, regardless of their empirical validity" (FPS: 21, italics added, also see Astley and Zammutto 1992). In other words, the strong focus on the fulfillment of prophecy based on false premises or a priori primed false beliefs and expectations suggests that humans are "mindless" and readily duped into false realities (see FPS: 8-9, 21, Gilovich 1991). Of course we recognize that individuals often do appear to behave mindlessly on what appear to be false premises. However, the problem in part is that scholars highlight systematically mindless behavior post hoc, but do not consider the extent to which these mindlessly-behaving individuals have the information needed (or, time or resources to gather additional information) to make an accurate judgment about the objective facts and about objective reality.

To illustrate, consider the case of a run on a bank induced by a random rumor; the run on a bank indeed provides the quintessential and original example of a false self-fulfilling prophecy (Merton 1948). In this case we may say that we have a false reality fulfilling itself — "false" because 
the bank in reality is not in trouble — and individuals are thus behaving "mindlessly" as they pull their money out. But, note that it may be perfectly rational on the part of individuals and agents to pull their money from the bank given the information that they have at that moment (cf. Banerjee 1992, Vaugirard 2005), though it may appear that they are mindlessly following the false prophecy. Thus the false prophecy fulfilling itself may better be attributed to the lack of information on the part of individuals and agents rather than being attributed to mindless, irrational behavior and false prophecy fulfillment.

Note also that the "initially false definition of the situation evoking a behavior which makes the originally false conception come true" (cf. Merton 1948: 195, italics in original; Merton's classic definition of self-fulfilling prophecy) may dynamically, in Bayesian fashion, self-correct itself over time as additional information becomes available about the underlying true objective realities of the situation, such as the solvency of the bank. It is thus important to recognize a temporal dynamic in false prophecy fulfillment, where individuals in Bayesian fashion update their expectancies (or, the prophecies) and behaviors as additional information about underlying objective facts and truth over time become available, thus correcting the initially false self-fulfilling facts and behaviors (cf. Henschel 1982, Kukla 1994). Individuals thus behave and take actions with the information that they have at that moment, based on reasoning and information that they find convincing (Boudon 1998, 2003). These reasons may of course be proven false post-hoc (suggesting mindless behavior), but reasons which a priori are rational on an individual basis given the information and time that is available (for an excellent overview, see McKenzie 2005). ${ }^{4}$

Implicit in our arguments then about objective reality providing a boundary for whether false prophecies and beliefs fulfill themselves is that we presume, counter to FPS (21), that individuals have abilities to judge objective reality, that they seek truth and information (Goldman 1999), and that they the are not necessarily easily or mindlessly duped (at least in the long-run) by just any false 
conceptions and beliefs. Individual conceptions of the environment and social reality, while potentially initially false given the lack of information or the lack of time to gather or process that information (cf. McKenzie 2003), are dynamically updated by individuals and organizations over time as additional information is received and considered. In short, allowing for an increased measure of rationality in human behavior is warranted (see McKenzie and Mikkelsen 2007, McKenzie 2003, 2005, Oaksford and Chater 1996, Funder 1987), and, this increase in rationality questions whether people truly buy into false definitions of situations and thus behave "mindlessly" (FPS: 21), specifically on a systemic basis (though they may behave mindlessly on an idiosyncratic, individual basis - Stanovich 1999, Krueger and Funder 2004). ${ }^{5}$

\section{The Boundary of Human Nature}

Human nature provides the second boundary for the self-fulfilling nature of theories. More generally, how human nature is specified is critical in social science research as forcefully noted by Herbert Simon: "nothing is more fundamental in setting our research agenda and informing our research methods than our view of the nature of the human beings whose behavior we are studying" (1985: 303). Specifically, a key question, then, when citing the self-fulfilling nature of theories is whether there are any constants or universals to human nature and human behavior, or, as emphasized by FPS when making their arguments (FPS: 8-10, cf. Ghoshal and Moran 1996), do "our beliefs about human nature [in self-fulfilling fashion] shape human nature itself" (Frank 1988: 237)? Unquestionably both are true, but, the central question at stake when evoking self-fulfilling prophecy, particularly its strong forms, is: to what extent? Which of the two predominantly drives human behavior and performance: human nature itself or beliefs about it?

FPS's conception of human nature is one of strong situational and social malleability. This conception of human nature is rooted in a foundational "first principle" of important strands of social science: Durkheim for example argues that "individual natures are merely the indeterminate material 
that the social factor molds and transforms" (1962: 106), or as put by Geertz: "[t]here is no such thing as human nature independent of culture" (1973: 49; cf. Mead 1928, Brandts et al 2004). Thus, social beliefs and expectations about human nature, rather than an underlying universal human nature itself, are given special emphasis in determining individual behavior. The argument of the malleability of human nature is also an underlying (though implicit) foundation for the many bodies of research cited as support by FPS for the falsely self-fulfilling nature of theories, specifically, research that notes the role that various external contingencies play in shaping and determining human behavior and perceptions of reality. These external contingencies include: others' beliefs (Frank 1988), language (Sapir 1911, 1929, Whorf 1956), expectations and perceptions (Rosenthal and Jacobson 1968), social stereotypes (Snyder, Tanke, and Berscheid 1977), and images (Miller 1999, cf. Bloor 1991) and so forth (see FPS: 8-15).

While we do not wish to question the importance of, for example, socialization processes, what is questionable is whether human nature truly is as malleable as suggested by FPS's thesis where even false beliefs, conceptions, language, expectations, priming of others about human nature in essence change and determine human nature itself? Aren't there universals and constants in human nature; what is the other side of the argument? As discussed, the fact that the economic assumption of agent omniscience or hyper-rationality has not fulfilled itself of course provides one excellent example of human nature as a boundary for what theories and expectations actually do fulfill themselves; but, there is now also a rich literature which has directly tested this boundary and noted the importance of constants in human nature.

Specifically, there is a large and ever-growing body of research that persuasively argues and shows that there is underlying universal human nature that deserves careful consideration (Chomsky 1957, 2003, Markozcy and Goldberg 1998, cf. Pinker 2002) — in essence questioning the strong malleability of human nature implied by FPS's thesis. ${ }^{6}$ Recent theoretical and empirical work in fact 
has tested and measured the relative effects of human nature versus prophecy. FPS indeed cite one strand of this work and debate (also see Ghoshal and Moran 1996), specifically highlighting the role that priming, expectancy, language and various other external contingencies and situational factors — for example, theories and assumptions that others have about an individual — play in determining individual behavior and performance (e.g., Kay and Ross 2003, Miller 1999). The work that FPS and others cite builds on classic studies of self-fulfilling prophecy that look at the "Pygmalion"-effect, for example where teacher expectations and beliefs about student capability (primed in an experimental laboratory setting) determine student outcomes (e.g., Rosenthal and Jacobson 1968, Dweck and Leggett 1988).

However, a different strand in social psychology also exists and questions these findings, in particular the effect-sizes of these findings. This research explicitly is cognizant of human nature and has empirically tested the extent to which other's expectations and beliefs fulfill themselves in individual behavior versus the extent to which there are real underlying individual-level determinants of behavior and performance. Specifically, theoretical and empirical work by social psychologists such as Jussim, Funder, Kenny and colleagues has shown that other's expectations and beliefs about individual behavior predict that behavior not because of self-fulfilling prophecy-effects, but rather, because beliefs and expectations about others' behaviors are relatively accurate - that is, they are rooted in actual characteristics of human nature rather than arbitrary or false beliefs about it (see Funder 1987, 1995, Jussim 1986, 1991, Kenny 1991, Kenny et al 2001). Furthermore, importantly, these expectations and beliefs about others, particularly when false, are dynamically updated over time (in Bayesian fashion - McKenzie and Mikkelsen 2007, Jussim 1991, also see Funder 1987, Jussim 1989).

Scholars have also been able to study the relative magnitudes of human nature (e.g., various dispositional characteristics) versus prophecy effects (e.g., beliefs or expectations about dispositions 
or human nature) through variance decomposition and through methods which have compared findings between experimental laboratory studies versus natural real-life settings. In part, the artificial environment of the experimental laboratory has, as an artifact of the experimental method that has been used in a majority of these studies, created the very types of short-term self-fulfilling prophecy-effects that FPS cite (see Jussim 1986, 1989, 1991). That is, once appropriate controls related to human nature are introduced (such as: individual dispositions, behaviors, interests, preferences, abilities, choices and so forth), and once testing is done in a natural environment rather than in a laboratory (or appropriate controls are included for the latter), and once prophecy effects are studied over time - the prophecy-effects relative to human nature-related effects become marginal to non-significant (see Jussim 1986, 1989, 1991, Jussim and Harber 2005, Madon et al. 1997, Smith et al. 2001). The significantly more important factors related to human nature, rather than the marginal and short-term effects of others' beliefs and prophecy about it, have now been shown to predominate; a finding that has been replicated in several meta-analyses (e.g., Funder 1995).

Of course we do not want to completely dismiss self-fulfilling prophecy effects. What is, however, important to note is that false beliefs about behavior, which might fulfill themselves in the short term, importantly get dynamically corrected and updated in social contexts. False effects are small and dissipate rather quickly over time as individual behavior gives clues or signals about actual factors and accurate beliefs related to human nature (Smith et al. 1999). The more general point here is that false "prophecy-effects" are dwarfed by accurate and correct assessment, that is, upon receiving further information we dynamically adjust and update our models accordingly (cf. McKenzie 2005). A better way, then, is to conceptualize beliefs and prophecy-effects with a “realistic accuracy model” (Funder 1987, 1995, Krueger et al 2003, Krueger and Funder 2004, Kruglanski 1989). In short, prophecies do shape reality, but false ones only marginally, with these marginal effects quickly dissipating over time. 
In all, human nature, then, provides a "limiting condition of prophecy fulfillment" (Jussim 1986). Put differently, behavior itself is a cause of beliefs and expectations rather than the other way around (Funder 1995). As discussed by Krueger and Funder (2004), scholars have fallen in the trap of over-emphasizing situational effects (self-fulfilling prophecy-effects being the specific case in point, Jussim 1991) at the expense of variables related to human nature (cf. Jussim 1989). Thus, with reference to FPS' critique of economics, it may be that self-interest - rightly understood - in fact provides a real underlying human motivation, rather than one that is falsely constructed.

\section{DEFENDING (ORGANIZATIONAL) ECONOMICS: THE OTHER SIDE OF THE}

\section{ARGUMENT}

FPS's arguments about the self-fulfilling nature of theories, specifically its strong form where even false theories fulfill themselves, use economics as the prime example. They specifically argue that the widespread acceptance, diffusion and teaching of economics has in self-fulfilling fashion adversely shaped individual behavior and management practice (also see Adler 2001, 2002, FPS, Ghoshal and Moran 1996, Ghoshal 2005, Pfeffer 2005, Khurana 2007). However, FPS and others have unnecessarily caricatured economics. While in the above sections we have established key boundaries for the self-fulfilling nature of theories, specifically using examples from economics and social psychology, in this section we more generally defend economics, specifically organizational economics. We first argue, in response to FPS, that there are significant and real (individual and collective and societal) benefits associated with the infusion of market-mechanisms into organizations (Zenger and Hesterly 1997), and thereafter we discuss self-interest rightly understood.

\section{Market-Mechanisms in Organizations}

In a major application of their argument, FPS (11-22) question the benefits of infusing market-mechanisms into organizations, specifically "market-like mechanisms" such as incentives, competition and so forth, or as they put it, "American-style management practices" that accentuate 
and create self-interest (FPS: 11-17). They argue that an overarching market-logic has crept into organizations, resulting in unnecessary downsizing, the "commodification" of employees and poor collective and social outcomes (FPS: 19-22). In general, the authors paint a very gloomy picture of efforts to infuse market-mechanisms into organizations, even explicitly longing for the better times of yesteryear: FPS (19) specifically highlight the organizations of six decades ago as meeting more of a "communal" or "familial" image and ideal (also see Adler 2001, Adler and Heckscher 2006). FPS (18-20) further argue that the rhetorical (cf. Barley and Kunda 1992, Eccles and Nohria 1992) metaphor of organizations as "community" or "family" has been replaced by a self-interested market metaphor: a self-fulfilling “rationalized institutional myth” (Meyer and Rowan 1977) with detrimental consequences for management practice and social outcomes. Others have, along similar lines, explicitly argued that organizational scholars should avoid "an economic approach to organizational analysis" and the "dangerous liaison with economics" (Pfeffer 1997: 192).

There are, however, very strong reasons to believe that the infusion of market-mechanisms into organizations reflects an emerging reality with substantial individual and collective benefits (Zenger and Hesterly 1997), rather than a self-fulfilling rhetorical device or myth with mostly negative consequences. Specifically, the work of Todd Zenger and many others shows that there are significant benefits associated with the infusion of "markets into hierarchy" (e.g., Zenger 1992, 1994, Zenger and Hesterly 1997, Zenger and Lazzarini 2004, Zenger and Marshall 2000). For example, the use of the quintessential market-like mechanism — "high-powered incentives" (Zenger and Hesterly 1997) — in organizations has proven a powerful tool for luring talent and motivating effort. As Zenger and Marshall show in their empirical analysis, "higher incentive-intensity triggers higher effort, lures superior talent, and generally yields higher performance levels" (2000: 150, also see Gerhart and Milkovich 1990, Teece 2003). In fact, organizational performance suffers significantly if individual incentives (or, "inducements and contributions") are not properly aligned (March and 
Simon 1958:130, cf. Simon 1947). For example, Zenger's (1994) work further shows how large organizations specifically "under-incentivize" the highest-performing individuals, resulting not only in the turnover of these individuals, but also resulting in the rather surprising "organizational diseconomies" where small organizations perform significantly better (by attracting better talent) given better incentive alignment and reward systems (see Zenger 1994, also see Zenger and Lazzarini 2004).

High-powered individual incentives of course are not a panacea. Specifically, as FPS note, the associated dispersion in pay and wages may also lead to overall dissatisfaction, social comparison, envy, productivity losses, and a more general lack of collaboration in organizations (Pfeffer and Langton 1993, Pfeffer 1997, Walster et al 1973 cf. Levine 1993). How, then, is this quandary resolved? Specifically, on the one hand, the negative consequences of pay dispersion would suggest that incentives should be more homogeneous and collective (Pfeffer and Langton 1993), while, on the other hand, the problems associated with the misalignment of incentives for high performers suggest that significant heterogeneity in pay is warranted and needed to optimally induce effort (Zenger 1992, 1994).

Recent market and organizational dynamics, however, suggest some promising solutions to the above quandary; FPS (18-20) in fact strongly question the efficacy of some of these marketdynamics and emerging organizational forms, though we believe that they have had significant individual and collective benefits (cf. Cappelli 1999). Specifically, "organizational disaggregation" and associated advances in organizational design and forms have allowed for a better alignment of talent and interests with individual incentives (Zenger and Hesterly 1997, also see Foss 2003). The disaggregation of organizations means that individuals increasingly work in smaller organizational settings --- thus for example circumventing problems of deindividuation (Festinger et al 1952) --given improvements in measurement and technology (cf. Brynjolfsson et al. 1994). These smaller organizations and organizational units are not only significantly better at aligning individual 
incentives with individual expertise, talent and effort (Bresnahan et al. 2002, also see Birch 1987), but the smaller size of disaggregated units also in part obviates issues of social comparison and envy (see Nickerson and Zenger 2008). As put by Zenger and Hesterly, "small firms can simply link pay to firm performance, deliver high-powered incentives, and largely avoid comparison issues altogether" (1997: 213). Furthermore, as shown by Cable and Judge (1994 1996), individuals can and do increasingly self-select to interact with "similar others" based not only on their abilities and interests and values (Schneider 1987) but also their own incentive-related preferences, and this selfselection mitigates against many of the problems (for example, by reducing the range of social comparison) noted by FPS with regard to the use of high-powered incentives in organizations.

Related to the disaggregation of organizations, increasingly prevalent professional services and partnership-type organizational forms also benefit directly from the infusion of marketmechanisms into organizations (see Teece 2003). As discussed by Greenwood and Empson (2003), principal-agent problems and agency costs are better avoided in partnerships as individual interests, abilities and effort naturally align themselves with outcomes as the principal is the agent. And, more to the point, the partnership model clearly benefits from the infusion of market-mechanisms into organizations, or "superior incentive systems" (Greenwood and Empson 2003: 313); specifically, the tournament-model (cf. Lazear and Rosen 1981) ensures that effort and talent are properly rewarded, and property rights are better linked to individuals in these knowledge-intensive settings. As noted by Teece: "with better incentive alignment" these partnership (and related) forms of organization "can begin a virtuous cycle of work freedom and high reward" (2003: 908, Birch 1987).

All in all, the infusion of markets into hierarchy, far from "commodifying" human capital, as suggested by FPS (19), rather radically elevates the status of human capital in better recognizing and rewarding individual effort and ability. Furthermore, recent advances in information technology, in how the employment relationship is specified (and associated organizational forms), have removed many of the problems that FPS highlight with the use of market-mechanisms in organizations (e.g., 
social comparison costs, social loafing --- Festinger, 1954, Williams et al 1981). While downsizing, as noted by FPS, clearly is a reality which management and employees have to grapple with, and the "free-agent"-model of the employment relationship certainly is far from perfect (FPS: 18), nonetheless, it must also on the other hand be recognized that recent organizational forms and market dynamics have resulted in increased freedom and choice for individuals, and again, in the better alignment of incentives (Zenger and Hesterly 1997, cf. Cappelli 1999). Thus, it needs to be noted that the emergence of new ways to specify the employment relationship and new organizational forms has also been driven by "a desire for autonomy and employment flexibility" on the part of individuals, which has further resulted in individual and societal benefits (Teece 2003: 906, cf. Zenger 1994, for an excellent historical analysis of incentives and resultant societal benefits, see Clark 2007).

Now, the markets-in-hierarchy intuition certainly does not suggest that incentives are the only solution: of course culture matters, relationships matter, trust matters (cf. Adler 2001, Williamson 1993). And, of course misaligned incentives lead to detrimental collective outcomes (Gibbon 1998, Kerr 1975, Prendergast 1999). But, the more important point here is that FPS's (1217) caricature of "American-style" payment systems and high-powered incentives is extreme, particularly as incentives have been a central concept since the foundations of organization science and theory, as is evident for example in March and Simon's rather extensive discussion of “payments" and "inducements and contributions" (1958: 83-111, also see Barnard's [1938] discussion of incentives and the "organizational equilibrium," cf. Mahoney 2006: 15, Teece 2003). And, FPS's caricature of incentives is also extreme as it does not recognize the many recent innovations in organizational forms; forms that in essence create better incentive alignment (Zenger and Hesterly 1997, also see Greenwood and Empson 2003, Teece 2003). ${ }^{7}$ 


\section{Self-Interest, Rightly Understood}

The picture of self-interest painted by FPS and others (e.g., Ghoshal 2005, Ghoshal and Moran 1996) is lopsided. ${ }^{8}$ Specifically, these scholars fail to recognize that self-interest, specifically self-interest "rightly understood," by no means precludes cooperation, organization, communitybuilding, trust, or for that matter, any other individual, relational, or organizational virtue (cf. Casson 1996, Jensen and Meckling 1998, Fehr and Gaechter 2000, Sobel 2005, Williamson 1993, Binmore 2006a, 2006b). In fact, self-interest is required and provides an important underlying mechanism and driver for realizing improved individual, organizational and societal-level outcomes. The reason economists often exalt self-interest is not because they ascribe particular moral virtue to self-interest (in fact, the type of "enlightened" self-interest we have in mind should completely be decoupled from ethics), but rather because they recognize that, in the words of the British economist, D.H. Robertson, self-interest is needed to economize on "that scarce resource Love, which we know, just as well as anybody else, to be the most precious thing in the world" (Robertson 1956: 23). The central idea is that because there are inherent limits to our capacity for reciprocating (time, cost, ability and so forth) and limits to how far we can and will extend our personal obligations, we need to leave much, including the fulfilment of our material needs, to markets driven by self-interest: to individual judgments about what best maximizes one's scarce resources such as time and effort. An even stronger argument asserts that even if "love" was universal, we would still need to rely on selfinterest and markets, because these are the best known mechanisms for making use of dispersed knowledge in society (Hayek 1945). Thus, entirely benevolent and altruistic agents would still face the problem of making efficient use of dispersed knowledge; in contrast, markets driven by selfinterest make efficient use of dispersed knowledge.

Such arguments essentially link self-interest at the individual-level with beneficial outcomes at the collective level. The initial intuition for this, of course, was provided by Adam Smith (cf. Werhane 1989), who famously pointed out that we do not expect to get the goods from the "butcher, 
the baker and the brewer" by appealing to their benevolence but by appealing to their self-interest. Smith's invisible hand explanation of the micro-macro link has individuals self-select into environments where they realize the best outcomes for themselves, but also, unintentionally, beneficially contributing to collective and societal outcomes (Clark 2007: 145-147, Frydman and Phelps 1983). The context of self-selection in labor markets perhaps provides an apt example of the “invisible hand.” Individuals select environments and organizations where they, in their own best judgment, can best maximize the returns from their knowledge and abilities, and, this also has widerscale benefits for society (cf. Zenger 1992, 1994, also see Cable and Judge 1994, 1996, Schneider 1987, Teece 2003).

In contrast, FPS focus wholly on the potentially negative collective outcomes of individual self-interest. While no economist condones immoral or unethical behavior, somehow organizational scholars have recently drawn explicit links between self-interest and recent corporate ethics scandals, asserting direct causal influences (e.g., Adler 2002, Pfeffer 2005, cf. Harris and Bromiley 2007). For example, Ghoshal provocatively argues that "many of the worst excesses of recent management practices have their roots in a set of ideas that have emerged from business school academics over the last 30 years," specifically referring to ideas diffusing from economics into business schools (2005: 75, cf. Khurana 2007). However, no direct links have been established between the diffusion and acceptance of economics and unethical behavior that meet any standards of scientific rigor: defections in game theory, based on experimental findings, simply do not equate with bad management practice or unethical behavior (FPS: 14). Furthermore, the artificially primed experimental situations where language is used to highlight self-interested economic behavior (see FPS: 16, Liberman et al. 2004) can simply be interpreted as efforts by the subjects to get short-term cues for behavior rather than evidence for economics "falsely" creating self-interested, unethical behavior (or, see Laband and Beil 1999). 
Overall, given the relatively short history of the corporate form and business education (cf. Khurana 2007), and without objective data (other than the particularly salient, recent business scandals), and without a relative comparison to previous periods, statements about economics falsely creating self-interest are premature. Surely self-interested behavior existed prior to the recent emergence of the neoclassical model of economics. In idealizing and advocating the organizational forms of decades ago, and in assigning virtues to organizational forms of the past (see FPS: 19, Adler and Heckscher 2006:14, 67-77), it seems that management scholars may have fallen in a similar type of trap of "retrospective idealization" as some anthropologists who long admired and advocated the peaceful and communal and historical arrangements associated with tribal life - secluded from markets, self and competition - though objective data has revealed that the worst of human excesses, self-interest and violence occurred during those exact time periods (see Keeley 1996, cf. Pinker 2002). On the other hand, it is after the introduction of market-promoting and incentiveenhancing institutions that both individual and societal welfare has radically improved on every measurable dimension (for an overview, see Clark 2007).

We of course do not mean to suggest that economics has all the answers. Scarcely so, we indeed have highlighted some of the problematic assumptions of economics (e.g., hyper-rationality) and noted problems with incentives (e.g., misalignment). But, our central point has been to highlight that there are vast benefits associated with both economic reasoning and market-mechanisms more generally, and thus organizational scholars should not be so quick to dismiss these positive elements of economics as they can significantly enhance our understanding of organizations.

\section{CONCLUSION}

The purpose of this paper has been to respond to recent arguments concerning the role that economics purportedly plays in adversely shaping human behavior, management practice, and 
organizational and societal outcomes (FPS). We have specifically addressed the key mechanism used by many to highlight why economics has unduly and adversely influenced human behavior and management practice — that is, the self-fulfilling nature of (even false) theories. We have explicated two key boundary conditions for the self-fulfilling nature of theories, that is, objective reality and human nature. An understanding of the implications of these two boundaries fundamentally changes the conclusions of FPS. Specifically, (false) theories do not arbitrarily influence behavior or practice; rather, theories tend to influence reality to the extent to which they approximate underlying objective reality, thus, for example, requiring a correct specification of human nature. "True" approximations or theories of reality, then, in turn also help shape reality, though the first-order role of theory — from the perspective of scientific realism — is to help explain, predict and understand reality (Popper 1972, Psillos 1999), and secondarily these more correct models then in turn shape reality and lead to scientific progress.

Economics, then, may actually offer some broad truths about human behavior, rather than merely being a rhetorical device or falsely self-fulfilling prophecy resulting in bad management practice and poor collective outcomes, as is argued by FPS. That is, some aspects of economics may well "hold sway" because they build off of a clear and general core model of human action and nature which is not that far removed from real human action and nature (cf. Jensen and Meckling 1998) and because economics has been fairly successful with respect to identifying real mechanisms - we have indeed highlighted recent work on the role of high-powered incentives in organizations as an example and case in point (e.g., Zenger and Hesterly 1997, Zenger and Marshall 2000).

In all, our effort here has been to provide the other side of the argument in response to FPS (and many others), to explicate key boundaries for the self-fulfilling nature of theories, and to note many of the benefits associated with the infusion of market-mechanisms into organizations. We certainly recognize that our arguments may be controversial to some, particularly as discussions 
about why and how theories influence reality closely mirror what appear to be fundamentally irreconcilable epistemological debates in philosophy (see Bloor 1991, Boghossian 2006, Bricmont and Sokal 2004, Brown 1994, Kuhn 1970, Latour 1999, Popper 1972). Nonetheless, given the rather one-sided recent discussions in management and social science outlets about how some theories falsely fulfill themselves and adversely shape human behavior - economics being the prime example — we have argued and shown that there is equally persuasive and voluminous support from the social sciences, philosophy, and organizational economics for differing conclusions. 


\section{REFERENCES}

Adler, P. S. 2001. Knowledge, trust and the future of capitalism. Organ. Sci. 12 214-234.

Adler, P. S. 2002. Corporate scandals: It's time for reflection in business schools. Acad. Management Executive 16 148-149.

Adler, P. S., J. Jermier. 2005. Developing a field with more soul: standpoint theory and public policy research for management scholars. Acad. Management J. 48 941-944.

Adler, P.S., C. Heckscher. 2006. The firm as a collaborative community: Reconstructing trust in the knowledge economy. Oxford University Press, Oxford.

Astley, W.G. 1985. Administrative science as socially constructed truth. Admin. Sci. Quart. 30 497-513.

Astley, W.G., R.F. Zammutto. 1992. Organization science, managers, and language games. Organ. Sci. 3 443-460.

Barnard, C. 1938. The function of the executive. Harvard University Press.

Banerjee, A. V. 1992. A simple model of herd behavior. Quart. J. Econom. 107 797-818.

Barley, S. R., G. Kunda. 1992. Design and devotion: The ebb and flow of rational and normative ideologies of control in managerial discourse. Admin. Sci. Quart. 37 1-30.

Barnes, B., D. Bloor. 1982. Relativism, rationalism and the sociology of knowledge. Hollis, M.,S. Lukes (eds). Rationality and Relativism. Cambridge: MIT Press, 21-47.

Berlin, B., P. Kay. 1969. Basic Color Terms: Their Universality and Evolution. University of California, Berkeley and Los Angeles.

Binmore, K. 2006a. Economic man - or straw man. A commentary on Henrich et al. Behavioral Brain Sci. 28 817-818.

Binmore, K. 2006b. Why do people cooperate? Politics, Philos. Econom. 5 81-96

Birch, D.L. 1987. Job Creation in America: How our Smallest Companies Put the Most People to Work. Free Press, New York.

Black, F., M. Scholes. 1973. The pricing of options and corporate liabilities. J Pol. Econ. 81 637-654.

Bloor, D. 1991. Knowledge and Social Imagery. Chicago University Press.

Boas, F. 1911. The Mind of Primitive Man. MacMillan, New York.

Boghossian, P. 2006. Fear of Knowledge. Oxford University Press.

Bonjour, L. 1998. In Defense of Pure Reason. London: Cambridge University Press.

Boudon, R. 1998. Social mechanisms without black boxes. In P. Hedstrom, R. Swedberg, Social Mechanisms: An Analytical Approach to Social Theory, Oxford University Press, 173-203. 
Boudon 2003. Limitations of rational choice theory. Amer. J. Sociol. 104 817-828.

Bourdieu, P. 1992. Invitation to a Reflexive Sociology. University of Chicago Press.

Brandts, J., T. Saijo, A. Schram. 2004. How universal is behavior? A four country comparison of spite and cooperation in voluntary contribution mechanisms. Public Choice 119 381-424.

Bresnahan, T., E. Brynjolfsson, L. Hitt. 2002. Information technology, workplace organization, and the demand for skilled labor: firm-level evidence. Quart. J. Econ. 117 339-76.

Bricmont, J., A. Sokal. 2004. Defense of a modest scientific realism. In Carrier, M., J. Roggenhofer, G. Kuppe, P. Blanchard. Knowledge and the World: Challenges Beyond the Science Wars. Hamburg: Springer-Verlag, 17-45.

Brown, D.E. 1991. Human universals. McGraw-Hill, New York.

Brown, J.R. 1994. Smoke and mirrors: How science reflects reality. Routledge, New York.

Brown, J.R. 2001. The Science Wars: An Opinionated Guide. Harvard University Press.

Brynjolfsson, E., T. Malone, V. Gurbaxani, A. Kambil. 1994. Does information technology lead to smaller firms. Management Sci. 40 1628-1644.

Cable, D.M., T.A. Judge. 1994. Pay preference and job search decisions: A person-organization fit perspective. Personnel Psych. 47 317-348.

Cable, D.M., T.A. Judge. 1996. Person-organization fit, job-choice decisions, and organizational entry. Org. Beh. Human Dec. Processes 67 294-311.

Callon, M. 1998. Introduction: The embeddedness of economic markets in economics. M. Callon ed. The Laws of the Market. Blackwell, Oxford 1-50.

Callon, M. 2007. What does it mean to say that economics is performative? In Do economists make markets: On the performativity of economics, MacKenzie, D. Muniesa, F., and Siu, L. Princeton University Press.

Cannella, A.A., R.L. Paetzold. 1994. Pfeffer's barriers to the advance of organizational science: A rejoinder. Acad. Management Rev. 19 331-341.

Cappelli, P. 1999. The New Deal at Work. Harvard Business School Press, Boston.

Casson, M. 1996. Economics and anthropology: Reluctant partners. Human Relations 49 1151-1180.

Chomsky, N. 1957. Syntactic Structures. Moutin, The Hague.

Chomsky, N. 2003. Cartesian Linguistics: The History of Rationalist Thought. New York: Cybereditions.

Clark, G. 2007. Farewell to Alms: A Brief Economic History of the World. Princeton University Press. 
Davis-Blake, A., J. Pfeffer. 1989. Just a mirage: The search for dispositional effects in organizational research. Acad. of Management Rev. 14 385-400.

Dumont, L. 1977. From Mandeville to Marx: The Genesis and Triumph of Economic Ideology. Chicago: University of Chicago Press.

Durkheim, E. 1962. The rules of the sociological method. Glencoe, Ill.: Free Press.

Dweck, C. S., E.L. Leggett. 1988. A social-cognitive approach to motivation and personality. Psych. Rev. 95 256-273.

Eccles, R. G., N. Nohria. 1992. Beyond the Hype: Rediscovering the Essence of Management. Harvard Business School Press, Boston.

Elster, J. 1989. Nuts and Bolts for the Social Sciences. Cambridge Univ. Press.

Fehr, E., S. Gaechter. 2000. Fairness and retaliation: The economics of reciprocity. J. Econom. Perspectives 14 159-181.

Felin, T., Hesterly, W.S. 2007. The knowledge-based view, nested heterogeneity, and new value creation: Philosophical considerations on the locus of knowledge. Acad. of Management Rev. 32 195-218.

Ferraro, F., J. Pfeffer, R.I. Sutton. 2005. Economics language and assumptions: How theories can become self-fulfilling. Acad. Management Rev. 30 8-24.

Festinger, L., A. Pepitone, T. Newcomb. 1952. Some consequences of de-individuation in a group. J. of Abnormal and Soc. Psych. 47 382--389.

Festinger, L. 1954. A theory of social comparison processes. Human Relations 7 117-158.

Foss, N.J. 2003. Selective intervention in internal hybrids: Interpreting and learning from the rise and decline of the oticon spaghetti organization. Organ. Sci. 14 331-349.

Fourcade-Gourinchas, M. 2004. A global theory of professionalization: The case of economics. Working paper, Department of Sociology, University of California, Berkeley.

Fourcade, M. 2007a. Theories of markets and theories of society. Amer. Beh. Sci. 50 1015-1034.

Fourcade, M. 2007b. The construction of a global profession: The transnationalization of economics. Amer. J. Sociol. 112 145-194.

Frank, R.H. 1988. Passion within reason: The strategic role of the emotions. New York: Norton.

Freeman, D. 1999. The Fateful Hoaxing of Margaret Mead: A Historical Analysis of her Samoan Research. Westview Press, Boulder, CO.

Freese, J., Li, J.C.A., Wade, L.D. 2003. The potential relevance's of biology to social inquiry. Annual Rev. Sociology 29 233-256.

Frey, B.S., M. Osterloh. 2005. Yes, managers should be paid like bureaucrats. J. Management Inquiry 14 96-111. 
Friedman, M. 1953. Essays in Positive Economics. Chicago: University of Chicago Press.

Frydman, R., Phelps, E. 1983. Individual Forecasting and Aggregate Outcomes. Cambridge Univ. Press, New York.

Funder, D.C. 1987. Errors and mistakes: Evaluating the accuracy of social judgment. Psych. Bull. 101 7590 .

Funder, D.C. 1995. On the accuracy of personality judgment: A realistic approach. Psych. Rev. 102 652670.

Geertz, C. 1973. The Interpretation of Cultures. Basic Books, New York.

Gerhart, B., G.T. Milkovich 1990. Organizational differences in managerial compensation and financial performance. Acad. Management. J. 33 663-691.

Ghoshal, S. 2003. Business schools share the blame for Enron. Financial Times, July 17.

Ghoshal, S. 2005. Bad management theories are destroying good management practices. Acad. of Management Learn. and Ed. 4 75-91.

Ghoshal, S., P.M. Moran. 1996. Bad for practice: A critique of the transaction cost theory. Acad. of Management Rev. 21 13-47.

Gibbons, R. 1998. Incentives in organizations. J. Econ. Persp. 12 115-132.

Giddens, A. 1990. The Consequences of Modernity. Polity Press, Cambridge.

Gigerenzer, G. and the ABC Research Group. 1999. Simple heuristics that make us smart. Oxford University Press.

Gilovich, T. 1991. How We Know What isn't So: The Fallibility of Human Reason in Everyday Life. The Free Press.

Gintis, H, R. Khurana. 2007. Corporate honesty and business education: A behavioral model. Working paper, Harvard Business School.

Goldman, A.I. 1999. Knowledge in a Social World. Oxford University Press.

Green, S.E. 2004. A rhetorical theory of diffusion. Acad. of Management Rev. 29 653-669.

Greenwood, R., L, Empson. 2003. The professional partnership: Relic or exemplary form of governance. Organ. Studies 24 909-933.

Grunberg, E., F. Modigliani. 1954. The predictability of social events. J. of Political Econom. 62 465478.

Grunberg, E. 1986. Predictability and reflexivity. Amer. J. Econom. Sociol. 45 475-488. 
Haack, S. 1998. Manifesto of a Passionate Moderate: Unfashionable Essays. Chicago: University of Chicago Press.

Harris, J., Bromiley, P. 2007. Incentives to cheat: The influence of executive compensation and firm performance on financial misrepresentation. Org Sci. 18 350-367.

Hayek, F.A. 1945. The use of knowledge in society. Amer. Econ. Rev. 35 519-530.

Heider, E.R., D.C. Olivier. 1972. The structure of the color space for naming and memory in two languages. Cognitive Psych. 3 337-354.

Henshel, R.L. 1982. The boundary of the self-fulfilling prophecy and the dilemma of social prediction. The British J. of Sociology 33 511-528.

Hollis, M. 1982. The social destruction of reality. M. Hollis, S. Lukes eds. Rationality and Relativism. Blackwell: Oxford, 67-86.

Jensen, M.C., W. Meckling. 1998. The nature of man. M.C. Jensen ed. Foundations of Organizational Strategy. Harvard University Press, Boston.

Jussim, L. 1986. The self-fulfilling prophecies - A theoretical and integrative approach. Psych. Rev. 93 429-445.

Jussim, L. 1989. Teacher expectations: Self-fulfilling prophecies, perceptual biases, and accuracy. $J$. Personality Soc. Psych. 57 469-480.

Jussim, L. 1991. Social-perception and social-reality: A reflection construction-model. Psych. Rev. 98 5473.

Jussim, L., K.D. Harber. 2005. Teacher expectations and self-fulfilling prophecies: Knowns and unknowns, resolved and unresolved controversies. Personality Soc. Psych. Rev. 9 131-155.

Kahneman, D., Tversky, A. 1996. On the reality of cognitive illusions. Psych. Rev. 103: 582-591.

Kay, P. 1999. Color categorization. R.A. Wilson, F.C. Keil eds. MIT Encyclopedia of the Cognitive Sciences. The MIT Press.

Kay, P., W. Kempton. 1984. What is the sapir-whorf hypothesis? Amer. Anthropologist 86 65-79.

Kay, P., T. Regier. 2003. Resolving the question of color naming universals. Proc. of the National Acad. of Sciences 100 9085-9089.

Kay, A.C., L. Ross. 2003. Nonconscious influence and conscious reflection: The interplay of implicit cues and explicit situational construals in the prisoner's dilemma. J Experimental Soc. Psych. 39 634-643.

Keeley, L.H. 1996. War Before Civilization. New York: Oxford University Press.

Kenny, D. A. 1991. A general model of consensus and accuracy in interpersonal perception. Psych. Rev. 98 155-163. 
Kenny, D.A., C.D. Mohr, M.J. Levesque. 2001. A social relations variance partitioning of dyadic behavior. Psych. Bull. 127 128-141.

Kerr, S. 1975. On the folly of rewarding A, while hoping for B. Acad. Manag. J. 18 769-783.

Khurana, R. 2007. From Higher Aims to Hired Hands: The Social Transformation of American Business Schools and the Unfulfilled Promise of Management as a Profession. Princeton University Press.

Kitcher, P. 2003. Science, Truth, and Democracy. Oxford University Press.

Knorr-Cetina. K. 1999. Epistemic Cultures: How the Sciences make Knowledge. Cambridge, MA: Harvard University Press.

Krueger, J.I., D.C. Funder. 2004. Towards a balanced social psychology: Causes, consequences and cures for the problem-seeking approach to social behavior and cognition. Behavioral Brain Sci. 27 313-327.

Krueger, J.I., J.F. Hasman, M. Acevedo, P. Villano. 2003. Perceptions of trait typicality in gender stereotypes: Examining the role of attribution and categorization processes. Personality Soc. Psych. Bull. 29 108-116.

Kruglanski, A.W. 1989. The psychology of being 'right': The problem of accuracy in social perception and cognition. Psych. Rev. 106 395-409.

Kukla, A. 1994. The structure of self-fulfilling and self-negating prophecies. Theor. Psych. 4 5-33.

Kuhn, T. 1970. The Structure of Scientific Revolutions. $2^{\text {nd }}$ edition (1st/ed 1962). University of Chicago Press, Chicago.

Laband, D.N., R.O. Beil. 1999. Are economists more selfish than other 'social' scientists. Public Choice 100 85-101.

Lakatos, I. 1976. Proofs and refutations. Cambridge: Cambridge University Press.

Latane, B., K. Williams, S. Harkins. 1979. Many hands make light the work: The causes and consequences of social loafing, J. Personality Soc. Psych. 37 822-832.

Latour, B., S. Woolgar. 1979. Laboratory Life: The Social Construction of Scientific Facts. Sage, London.

Latour, B.S. 1999. Pandora's hope: Essays on the Reality of Science Studies. Harvard University Press.

Lazear, E., S. Rosen. 1981. Rank-order tournaments as optimum labor contracts. J. Pol. Econom. 89 841861.

Liberman, V., S. Samuels, L. Ross, 2004. The name of the game: Predictive power of reputation vs. situational labels in determining prisoner's dilemma game moves. Personality Soc.Psych.Bull. $301175-$ 1185 .

Lucas, R.E. 1977. Understanding Business Cycles. Studies in Business Cycle Theory. MIT Press, Cambridge, MA. 
MacKenzie, D. 2006. An Engine, Not a Camera: How Financial Models Shape Markets. MIT Press, Cambridge, MA.

MacKenzie, D., Y. Millo. 2003. Constructing a market, performing theory. The historical sociology of a financial derivatives market. Amer. J. Sociol. 109 107-145.

Madon, S. J., L. Jussim, J. Eccles. 1997. In search of the powerful self-fulfilling prophecy. J. Personality Soc. Psych. 72 791-809.

Mahoney, J. 2006. Economic Foundations of Strategy. Sage: New York.

Malotki, E. 1983. Hopi Time: A Linguistic Analysis of the Temporal Concepts in the Hopi Language. Mouton, Berlin.

March, J. \& Simon, H. 1958. Organizations. New York: John Wiley.

Markoczy, L., J. Goldberg. 1998. Management, organization and human nature: An introduction.

Managerial Decision Econom. 19 387-409.

Martin, L. 1986. Eskimo words for snow: A case study in the genesis and decay of an anthropological example. Amer. Anthropologist 88 418-23.

McKenzie, C.R.M. 2003. Rational models as theories - not standards - of behavior. Trends Cogn. Sci. 7 403-406.

McKenzie, C. R. M. 2005. Judgment and decision making. K. Lamberts R. L. Goldstone eds. Handbook of Cognition. Sage, London, 321-338.

McKenzie, C.R.M., L.A. Mikkelsen. 2007. A bayesian view of covariation assessment. Cognitive Psych. $5433-61$.

McKinley, W., M.A. Mone, G. Moon. 1999. Determinants and development of schools in organization theory. Acad. Management Rev. 24 634-648.

Mead, M. 1928. Coming of Age in Samoa: A Psychological Study of Primitive Youth for Western Civilization. Blue Ribbon Books, New York.

Merton, R. K. 1948. The self-fulfilling prophecy. Antioch Rev. 8 193-210.

Meyer, J. W., B. Rowan. 1977. Institutionalized Organizations: Formal Structure as Myth and Ceremony. Amer. J. Sociol. 83 340-363.

Miller, D.T. 1999. The norm of self-interest. Amer. Psych. 54 1053-1060.

Nagel, T. 1961. The Structure of Science: Problem in the Logic of Scientific Explanation. Harcourt, Brace and World.

Nickerson, J., T. Zenger. 2008. Envy, comparison costs, and the economic theory of the firm. Strat. Man. $J$. forthcoming. 
Niiniluoto, I. 1984. Is science progressive? Springer-Verlag: Amsterdam.

Oaksford, M., N. Chater. 1996. Rational explanation of the selection task. Psych. Rev. 103 381-391.

Pfeffer, J. 1997. New Directions for Organization Theory: Problems and Prospects. Oxford University Press: Oxford.

Pfeffer, J. 2005. Why do bad management theories persist? A comment on Ghoshal. Acad. Management Learn. Ed. 4 96-100.

Pfeffer, J., Langton, N. 1993. The effect of wage dispersion on satisfaction, productivity and working collaboratively: Evidence from college and university faculty. Administrative Sci. Quart. 38: 382-407.

Pinker, S. 2002. The Blank Slate: The Modern Denial of Human Nature. Penguin Books.

Pinker, S. 2007. The Stuff of Thought: Language as a Window into Human Nature. New York: Viking Adult.

Popper, K. 1957. The Poverty of Historicism. Harper and Row, New York.

Popper, K. 1972. Objective knowledge. Oxford University Press.

Prendergast, C. 1999. The provision of incentives in firms. J. Econ. Lit. 37 7-63.

Psillos, S. 1999. Scientific Realism: How Science Tracks Truth. New York and London: Routledge.

Pullum, G.K. 1991. The Great Eskimo Vocabulary Hoax and Other Irreverent Essays on the Study of Language. University of Chicago Press.

Robertson, D.H. 1956. What does the economist economize? Economic Commentaries. Staples Press Limited, London.

Rosenthal, R., L. Jacobson. 1968. Pygmalion in the Classroom: Teacher Expectations and Pupil's Intellectual Development. Holt, New York.

Sapir, E. 1911. Language and environment. Amer. Anthropologist 14 226-242.

Sapir, E. 1929. The status of linguistics as science. Language 5 207-214

Schneider, B. 1987. The people make the place. Personnel Psych. 40 437-454.

Simon, H.A. 1954. Bandwagon and underdog effects in the possibility of election predictions. Public Opinion Quart. 18 245-253.

Simon, H.A. 1985. Human nature in politics. Amer. Political Sci. Rev. 79 293-304.

Smith, A., L. Jussim, J. Eccles. 1999. Do self-fulfilling prophecies accumulate, dissipate, or remain stable over time? J. Personality Soc. Psych. 77 548-565.

Sobel, J. 2005. Interdependent preferences and reciprocity. J. Econom. Lit. 43 392-436. 
Snyder, M., E.D. Tanke, E. Berscheid. 1977. Social perception and interpersonal behavior: On the selffulfilling nature of social stereotypes. J. Personality Soc. Psych. 35 656-666.

Stanovich, K.E. 1999. Who is Rational?Studies in Individual Differences in Reasoning. New York: Laurence Erlbaum.

Stanovich, K.E., R.F. West 2000. Individual differences in reasoning: Implications for the rationality debate. Behavioral Brain Sci. 23 645-665.

Teece, D. 2003. Expert talent and the design of (professional services) firms. Indust. Corporate Change 12 895-916.

Thomas, W. I. 1923. The Unadjusted Girl : With Cases and Standpoint for Behavior Analysis. Little, Brown: Boston, MA.

Vaugirard, V. 2005. Beliefs, bailouts, and spread of bank panics. Bull. Econom. Res. 57 93-107.

Werhane, P. 1989. The role of self-interest in Adam Smith's Wealth of Nations. J. Philos. 86 669-680.

Whorf, B. 1956 Language, Thought, and Reality. Wiley, London.

Walster, E., E. Berscheid, G.W. Walser. 1973. New directions in equity research. J. Personality Soc. Psych. 25 151-176.

Williams, K., S. Harkins, B. Latane. 1981. Identifiability as a deterrent to social loafing: Two cheering experiments. J. Personality Soc. Psych. 40 303-311.

Williamson, O.E. 1993. Calculativeness, trust, and economic organization. J. Law Econom. 36 453-486.

Williamson, O.E. 1996. Economic organization: A case for candor. Acad. Management Rev.21 48-57.

Zenger, T.R. 1992. Why do employers only reward extreme performance? Examining the relationship among performance, pay, and turnover. Admin. Sci. Quart. 37 198-219.

Zenger, T.R. 1994. Explaining organizational diseconomies of scale in research-and-development: Agency problems and the allocation of engineering talent, ideas, and effort by firm size. Management Sci. 40 708-729.

Zenger, T.R., W.S. Hesterly. 1997. The disaggregation of corporations: Selective intervention, highpowered incentives, and molecular units. Organ. Sci. 8 209-222.

Zenger, T.R. \& Lazzarini, S.G. 2004. Compensating for innovation: Do small firms offer high-powered incentives that lure talent and motivate effort. Man.Dec.Econ. 25: 329-345.

Zenger, T.R., Marshall, C.R. 2000. Determinants of incentive intensity in group-based rewards. Acad. Man. J. 43 149-163. 


\title{
ENDNOTES
}

\begin{abstract}
${ }^{1}$ FPS argue that the economic language of self-interest and competition creates self-interested and competitive behavior. FPS argue more generally, that "language affects what people see, how they see it, and the social categories and descriptors they use to interpret their reality. It shapes what people notice and ignore and what they believe is and is not important" (FPS: 9, also see Astley 1985, Bloor 1991, Latour 1999). However, FPS thesis of "linguistic determinism," originally conceived of in anthropology (specifically see Boas 1911, Sapir 1911, 1929, Whorf 1956; cf. Kay and Kempton 1984), has been directly challenged and questioned by linguists and psychologists. For example, a vast body of research in psychology shows that despite large heterogeneity in color names and categories across languages, individuals nonetheless see reality (in this case, colors) in the same fashion (see e.g., Berlin and Kay 1969, Heider and Olivier 1972, Kay 1999). In other words, this research shows that independent of the language associated with colors, individuals nonetheless see and experience reality in similar fashion, thus providing support for an objective and universal reality. For a large list of references (in numerous domains of psychology) and an exhaustive overview of problems with the thesis of language strongly influencing behavior, thought and perceptions of reality, see Pinker 2002, 2007.
\end{abstract}

${ }^{2}$ There are many variants of scientific realism (Bricmont and Sokal 2004, Kitcher 2003, Popper, 1972; Psillos, 1999), but, the contrast between these variants of realism and FPS's underlying epistemological approach (e.g., see their citations of MacKenzie, Dumont etc) is large enough that making fine-grained distinctions of realism is not necessary for our arguments. That said, we might note that what we are advocating here reflects a "moderate" scientific realism (cf. Haack 1998), which recognizes that 1) theories of course can also be wrong (though, they get corrected over time and progress is the norm of science), and 2) that theories are only approximations of reality rather than capital-T "Truth."

${ }^{3}$ The nature of economic theories and models themselves, it is argued, then is explicitly (though this remains implicit in most work, see MacKenzie, 2006) arbitrary in nature (i.e. their truth value is not of interest), specifically as it is the social, technological and political factors, rather than the models themselves, that receive primacy in determining whether a theory obtains. In line with this, Michel Callon argues that economic models and theories are "arbitrary conventions" (2007: 321-323).

${ }^{4}$ To briefly dive more carefully into this point of how individuals are falsely duped into behaving in certain ways, it is instructive to see how self-fulfilling false prophecies versus self-destroying false prophecies are used in the extant management literature. That is, an appeal to self-defeating false prophecy suggests that individuals have an ability to judge objective reality and to make appropriate judgments - to act counter to the false prophecy - while falsely selffulfilling prophecies suggest that individuals, as noted by FPS (19), "mindlessly" duped into behaving falsely. So, a brief and rough analysis of the top organizational journals (in JSTOR, including the following management journals: Organization Science, Administrative Science Quarterly, Academy of Management Review, Academy of Management Journal) reveals that the term "self-fulfilling prophecy" is invoked over 2000+ times in these journals (adding the "Pygmalion effect" to this count would radically tip the scales even further). Most always the connotation is that individuals have been falsely led to believe and act in certain ways that are individually or collectively hurtful. On the other hand, "self-defeating" (or "destroying" or "negating") appears only 24 times; selfdefeating prophecies again are (largely) situations where individuals act against false beliefs and false expectations, suggesting a measure of rationality. (We of course understand that the concept of self-fulfilling versus -destroying prophecies can be used to make opposing arguments depending on whether the prophecies are specified as false or true, though, most of the literature generally points to fulfillment in the case of false situations.) So, when a scholar or subject "learns" the potential for, or existence of, some kind of cognitive bias or error, they then can deliberately ensure that they don't "fall for it," (presuming they have enough information on probabilities etc). Grunberg points out that economists "... were and apparently still are concerned mainly with self-defeating public prediction. Sociologists seem to be interested more in self-fulfilling ones" (1986: 476). In sum, while Ghoshal and Moran (1996), FPS, and Ghoshal (2005) highlight self-fulfilling prophecies, prophecies may also be self-defeating or selfnegating (Elster 1989). When, how, and why one or the other occurs (self-fulfilling or defeating) is in part articulated in our discussion of objective reality as a boundary (in particularly in our discussion of rationality) and also implied in our discussion of human nature. 
${ }^{5}$ We are of course aware of research which has questioned human rationality and highlighted its problems and biases (e.g., Kahneman and Tversky 1996); and, as we have discussed, hyper-rationality or omniscience of course suggests an extreme that simply is not true. However, that said, recent theoretical and empirical research by social psychologists such as McKenzie, Krueger, Oaksford, Funder, Stanovich, Gigerenzer and numerous others has quite persuasively shown that an increased measure of rationality in human decision-making is warranted - specifically, biases are efficient and smart heuristics in information-deprived situations. Furthermore, some of the problems of "mindless behavior" and human rationality in the past have had more to do with methodological misspecifications on the part of scholars than misspecification on the part of the subjects that are being studied and labeled irrational (see Krueger and Funder 2004). That is, when looked at post hoc, it has appears as if people are quite irrational and readily duped into behaving falsely and making poor decisions - as the case of a run on a bank suggests. However, recent calibrations and corrections to models of rationality and decision-making - specifically, calibrations that account for (a) information availability (at the time of the decision), (b) time and (c) individual differences - have suggested that models highlighting systematic human irrationality need to be amended, and decision-making is driven by efficient heuristics suited for the complex environments that individuals and organizations operate in (see Funder 1987, Gigerenzer et al. 1999, Krueger and Funder 2004, McKenzie 2003, 2005, McKenzie and Mikkelsen 2007, Oaksford and Chater 1996, Stanovich 1999, Stanovich and West 2000).

${ }^{6}$ Taking human nature seriously has wide implications for strong forms of self-fulfilling prophecy where it is suggested that socially constructed beliefs of others in essence create and construct human nature itself. However, there has been an increasing recognition in other disciplines about the need to consider human nature, for example in sociology (see Freese, Li and Wade 2003), and in anthropology (see e.g., Freeman 1999, Malotki 1983, Martin 1986, Pinker 2002; Pullum 1991, Pinker 2002).

${ }^{7}$ One can turn the tables on FPS's argument and say that their situational thesis - specifically, rather than the thesis focusing on the benefits of market-mechanisms in organizations (cf. Zenger and Hesterly 1997) "commodifies" employees. That is, while the markets-in-hierarchy intuition explicitly recognizes heterogeneity in human capital and focuses on appropriately rewarding individual effort and talent (see Nickerson and Zenger 2008, Zenger 1994, Zenger and Marshall 2000), FPS's situational logic, on the other hand, logically implies a priori individual-level homogeneity as all of the explanatory burden is placed on organization-level determinants of individual competence and organizational performance (Davis-Blake and Pfeffer 1989, cf. Cable and Judge 1994, 1996, Schneider 1987). In short, if organizations indeed are "strong situations," as argued by Davis-Blake and Pfeffer (1989) and clearly implied in the arguments of FPS, then matters such as turnover and other individual-level factors (many of which are central to human capital) must be considered theoretically more peripheral. Overall, FPS mis-specify sources of underlying heterogeneity. For a more thorough discussion about the underlying need to appropriately specify individual and organizational [nested] heterogeneity and homogeneity, see Felin and Hesterly 2007.

${ }^{8}$ Note that here we do not cover the negative side of self-interest, specifically self-interest seeking "with guile," given Williamson's thorough response to this issue (specifically see Williamson 1996, cf. Ghoshal and Moran 1996). That is, TCE prescribes institutions to guard against collectively-hurtful self-interest-seeking behavior, given that some (not all) people indeed do act in collectively hurtful, unethical ways. 


\section{SMG - Working Papers \\ www.cbs.dk/smg \\ 2003}

2003-1: Nicolai J. Foss, Kenneth Husted, Snejina Michailova, and Torben Pedersen: Governing Knowledge Processes: Theoretical Foundations and Research Opportunities.

2003-2: Yves Doz, Nicolai J. Foss, Stefanie Lenway, Marjorie Lyles, Silvia Massini, Thomas P. Murtha and Torben Pedersen: Future Frontiers in International Management Research: Innovation, Knowledge Creation, and Change in Multinational Companies.

2003-3: Snejina Michailova and Kate Hutchings: The Impact of In-Groups and OutGroups on Knowledge Sharing in Russia and China CKG Working Paper.

2003-4: Nicolai J. Foss and Torben Pedersen: The MNC as a Knowledge Structure: The Roles of Knowledge Sources and Organizational Instruments in MNC Knowledge Management CKG Working Paper.

2003-5: Kirsten Foss, Nicolai J. Foss and Xosé H. Vázquez-Vicente: “Tying the Manager’s Hands": How Firms Can Make Credible Commitments That Make Opportunistic Managerial Intervention Less Likely CKG Working Paper.

2003-6: Marjorie Lyles, Torben Pedersen and Bent Petersen: Knowledge Gaps: The Case of Knowledge about Foreign Entry.

2003-7: Kirsten Foss and Nicolai J. Foss: The Limits to Designed Orders: Authority under "Distributed Knowledge" CKG Working Paper.

2003-8: Jens Gammelgaard and Torben Pedersen: Internal versus External Knowledge Sourcing of Subsidiaries - An Organizational Trade-Off.

2003-9: Kate Hutchings and Snejina Michailova: Facilitating Knowledge Sharing in Russian and Chinese Subsidiaries: The Importance of Groups and Personal Networks Accepted for publication in Journal of Knowledge Management.

2003-10: Volker Mahnke, Torben Pedersen and Markus Verzin: The Impact of Knowledge Management on MNC Subsidiary Performance: the Role of Absorptive Capacity CKG Working Paper.

2003-11: Tomas Hellström and Kenneth Husted: Mapping Knowledge and Intellectual Capital in Academic Environments: A Focus Group Study Accepted for publication in Journal of Intellectual Capital CKG Working Paper.

2003-12: Nicolai J Foss: Cognition and Motivation in the Theory of the Firm: Interaction or "Never the Twain Shall Meet"? Accepted for publication in Journal des Economistes et des Etudes Humaines CKG Working Paper.

2003-13: Dana Minbaeva and Snejina Michailova: Knowledge Transfer and Expatriation Practices in MNCs: The Role of Disseminative Capacity.

2003-14: Christian Vintergaard and Kenneth Husted: Enhancing Selective Capacity Through Venture Bases. 


\section{4}

2004-1: Nicolai J. Foss: Knowledge and Organization in the Theory of the Multinational Corporation: Some Foundational Issues

2004-2: Dana B. Minbaeva: HRM Practices and MNC Knowledge Transfer

2004-3: Bo Bernhard Nielsen and Snejina Michailova: Toward a Phase-Model of Global Knowledge Management Systems in Multinational Corporations

2004-4: Kirsten Foss \& Nicolai J Foss: The Next Step in the Evolution of the RBV: Integration with Transaction Cost Economics

2004-5: Teppo Felin \& Nicolai J. Foss: Methodological Individualism and the Organizational Capabilities Approach

2004-6: Jens Gammelgaard, Kenneth Husted, Snejina Michailova: Knowledge-sharing Behavior and Post-acquisition Integration Failure

2004-7: Jens Gammelgaard: Multinational Exploration of Acquired R\&D Activities

2004-8: Christoph Dörrenbächer \& Jens Gammelgaard: Subsidiary Upgrading? Strategic Inertia in the Development of German-owned Subsidiaries in Hungary

2004-9: Kirsten Foss \& Nicolai J. Foss: Resources and Transaction Costs: How the Economics of Property Rights Furthers the Resource-based View

2004-10: Jens Gammelgaard \& Thomas Ritter: The Knowledge Retrieval Matrix: Codification and Personification as Separate Strategies

2004-11: Nicolai J. Foss \& Peter G. Klein: Entrepreneurship and the Economic Theory of the Firm: Any Gains from Trade?

2004-12: Akshey Gupta \& Snejina Michailova: Knowledge Sharing in Knowledge-Intensive Firms: Opportunities and Limitations of Knowledge Codification

2004-13: Snejina Michailova \& Kate Hutchings: Knowledge Sharing and National Culture: A Comparison Between China and Russia

\section{5}

2005-1: Keld Laursen \& Ammon Salter: My Precious - The Role of Appropriability Strategies in Shaping Innovative Performance

2005-2: Nicolai J. Foss \& Peter G. Klein: The Theory of the Firm and Its Critics: A Stocktaking and Assessment

2005-3: Lars Bo Jeppesen \& Lars Frederiksen: Why Firm-Established User Communities Work for Innovation: The Personal Attributes of Innovative Users in the Case of Computer-Controlled Music

2005-4: Dana B. Minbaeva: Negative Impact of HRM Complementarity on Knowledge Transfer in MNCs

2005-5: Kirsten Foss, Nicolai J. Foss, Peter G. Klein \& Sandra K. Klein: Austrian Capital 
Theory and the Link Between Entrepreneurship and the Theory of the Firm

2005-1: Nicolai J. Foss: The Knowledge Governance Approach

2005-2: Torben J. Andersen: Capital Structure, Environmental Dynamism, Innovation Strategy, and Strategic Risk Management

2005-3: Torben J. Andersen: A Strategic Risk Management Framework for Multinational Enterprise

2005-4: Peter Holdt Christensen: Facilitating Knowledge Sharing: A Conceptual Framework

2005-5 Kirsten Foss \& Nicolai J. Foss: Hands Off! How Organizational Design Can Make Delegation Credible

2005-6 Marjorie A. Lyles, Torben Pedersen \& Bent Petersen: Closing the Knowledge Gap in Foreign Markets - A Learning Perspective

2005-7 Christian Geisler Asmussen, Torben Pedersen \& Bent Petersen: How do we Capture "Global Specialization" when Measuring Firms' Degree of internationalization?

2005-8 Kirsten Foss \& Nicolai J. Foss: Simon on Problem-Solving: Implications for New Organizational Forms

2005-9 Birgitte Grøgaard, Carmine Gioia \& Gabriel R.G. Benito: An Empirical Investigation of the Role of Industry Factors in the Internationalization Patterns of Firms

2005-10 Torben J. Andersen: The Performance and Risk Management Implications of Multinationality: An Industry Perspective

2005-11 Nicolai J. Foss: The Scientific Progress in Strategic Management: The case of the Resource-based view

2005-12 Koen H. Heimeriks: Alliance Capability as a Mediator Between Experience and Alliance Performance: An Empirical Investigation Into the Alliance Capability Development Process

2005-13 Koen H. Heimeriks, Geert Duysters \& Wim Vanhaverbeke: Developing Alliance Capabilities: An Empirical Study

2005-14 JC Spender: Management, Rational or Creative? A Knowledge-Based Discussion

\section{6}

2006-1: Nicolai J. Foss \& Peter G. Klein: The Emergence of the Modern Theory of the Firm

2006-2: Teppo Felin \& Nicolai J. Foss: Individuals and Organizations: Thoughts on a Micro-Foundations Project for Strategic Management and Organizational Analysis

2006-3: Volker Mahnke, Torben Pedersen \& Markus Venzin: Does Knowledge Sharing 
Pay? An MNC Subsidiary Perspective on Knowledge Outflows

2006-4: Torben Pedersen: Determining Factors of Subsidiary Development

2006-5 Ibuki Ishikawa: The Source of Competitive Advantage and Entrepreneurial Judgment in the RBV: Insights from the Austrian School Perspective

2006-6 Nicolai J. Foss \& Ibuki Ishikawa: Towards a Dynamic Resource-Based View: Insights from Austrian Capital and Entrepreneurship Theory

2006-7 Kirsten Foss \& Nicolai J. Foss: Entrepreneurship, Transaction Costs, and Resource Attributes

2006-8 Kirsten Foss, Nicolai J. Foss \& Peter G. Klein: Original and Derived Judgement: An Entrepreneurial Theory of Economic Organization

2006-9 Mia Reinholt: No More Polarization, Please! Towards a More Nuanced Perspective on Motivation in Organizations

2006-10 Angelika Lindstrand, Sara Melen \& Emilia Rovira: Turning social capital into business? A study of Swedish biotech firms' international expansion

2006-11 Christian Geisler Asmussen, Torben Pedersen \& Charles Dhanaraj: Evolution of Subsidiary Competences: Extending the Diamond Network Model

2006-12 John Holt, William R. Purcell, Sidney J. Gray \& Torben Pedersen: Decision Factors Influencing MNEs Regional Headquarters Location Selection Strategies

2006-13 Peter Maskell, Torben Pedersen, Bent Petersen \& Jens Dick-Nielsen: Learning Paths to Offshore Outsourcing - From Cost Reduction to Knowledge Seeking

2006-14 Christian Geisler Asmussen: Local, Regional or Global? Quantifying MNC Geographic Scope

2006-15 Christian Bjørnskov \& Nicolai J. Foss: Economic Freedom and Entrepreneurial Activity: Some Cross-Country Evidence

2006-16 Nicolai J. Foss \& Giampaolo Garzarelli: Institutions as Knowledge Capital: Ludwig M. Lachmann's Interpretative Institutionalism

2006-17 Koen H. Heimriks \& Jeffrey J. Reuer: How to Build Alliance Capabilities

2006-18 Nicolai J. Foss, Peter G. Klein, Yasemin Y. Kor \& Joseph T. Mahoney: Entrepreneurship, Subjectivism, and the Resource - Based View: Towards a New Synthesis

2006-19 Steven Globerman \& Bo B. Nielsen: Equity Versus Non-Equity International Strategic Alliances: The Role of Host Country Governance

\section{7}

2007-1 Peter Abell, Teppo Felin \& Nicolai J. Foss: Building Micro-Foundations for the Routines, Capabilities, and Performance Links 
2007-2 Michael W. Hansen, Torben Pedersen \& Bent Petersen: MNC Strategies and Linkage Effects in Developing Countries

2007-3 Niron Hashai, Christian G. Asmussen, Gabriel R.G. Benito \& Bent Petersen: Predicting the Diversity of Foreign Entry Modes

2007-4 Peter D. Ørberg Jensen \& Torben Pedersen: Whether and What to Offshore?

2007-5 Ram Mudambi \& Torben Pedersen: Agency Theory and Resource Dependency Theory: Complementary Explanations for Subsidiary Power in Multinational Corporations

2007-6 Nicolai J. Foss: Strategic Belief Management

2007-7 Nicolai J. Foss: Theory of Science Perspectives on Strategic Management Research: Debates and a Novel View

2007-8 Dana B. Minbaeva: HRM Practices and Knowledge Transfer in MNCs

2007-9 Nicolai J. Foss: Knowledge Governance in a Dynamic Global Context: The Center for Strategic Management and Globalization at the Copenhagen Business School

2007-10 Paola Gritti \& Nicolai J. Foss: Customer Satisfaction and Competencies: An Econometric Study of an Italian Bank

2007-11 Nicolai J. Foss \& Peter G. Klein: Organizational Governance

2007-12 Torben Juul Andersen \& Bo Bernhard Nielsen: The Effective Ambidextrous Organization: A Model of Integrative Strategy Making Processes.

\section{8}

2008-1 Kirsten Foss \& Nicolai J. Foss: Managerial Authority When Knowledge is Distributed: A Knowledge Governance Perspective

2008-2 Nicolai J. Foss: Human Capital and Transaction Cost Economics.

2008-3 Nicolai J. Foss \& Peter G. Klein: Entrepreneurship and Heterogeneous Capital.

2008-4 Nicolai J. Foss \& Peter G. Klein: The Need for an Entrepreneurial Theory of the Firm.

2008-5 Nicolai J. Foss \& Peter G. Klein: Entrepreneurship: From Opportunity Discovery to Judgment.

2008-6 Mie Harder: How do Rewards and Management Styles Influence the Motivation to Share Knowledge?

2008-7 Bent Petersen, Lawrence S. Welch \& Gabriel R.G. Benito: Managing the Internalisation Process - A Theoretical Perspective.

2008-8 Torben Juul Andersen: Multinational Performance and Risk Management Effects: Capital Structure Contingencies. 
2008-9 Bo Bernard Nielsen: Strategic Fit and the Role of Contractual and Procedural Governance in Alliances: A Dynamic Perspective.

2008-10 Line Gry Knudsen \& Bo Bernhard Nielsen: Collaborative Capability in R\&D Alliances: Exploring the Link between Organizational and Individual level Factors.

2008-11 Torben Juul Andersen \& Mahesh P. Joshi: Strategic Orientations of Internationalizing Firms: A Comparative Analysis of Firms Operating in Technology Intensive and Common Goods Industries.

2008-12 Dana Minbaeva: HRM Practices Affecting Extrinsic and Intrinsic Motivation of Knowledge Receivers and their Effect on Intra-MNC Knowledge Transfer.

2008-13 Steen E. Navrbjerg \& Dana Minbaeva: HRM and IR in Multinational Corporations: Uneasy Bedfellows?

2008-14 Kirsten Foss \& Nicolai J. Foss: Hayekian Knowledge Problems in Organizational Theory.

2008-15 Torben Juul Andersen: Multinational Performance Relationships and Industry Context.

2008-16 Larissa Rabbiosi: The Impact of Subsidiary Autonomy on MNE Knowledge Transfer: Resolving the Debate.

2008-17 Line Gry Knudsen \& Bo Bernhard Nielsen: Organizational and Individual Level Antecedents of Procedural Governance in Knowledge Sharing Alliances.

2008-18 Kirsten Foss \& Nicolai J. Foss: Understanding Opportunity Discovery and Sustainable Advantage: The Role of Transaction Costs and Property Rights.

2008-19 Teppo Felin \& Nicolai J. Foss: Social Reality, The Boundaries of Self-fulfilling Prophecy, and Economics. 